\title{
ERASMUS+ PROGRAMME SEEN FROM THE EYES OF POTENTIAL BENEFICIARIES - DIRECT RESEARCH CARRIED OUT WITH STUDENTS -
}

\author{
Bogdan Vasile Nichifor, \\ "Vasile Alecsandri" University of Bacau, \\ bogdan.nichifor@ub.ro \\ Laura Cătălina Ţimiraş, \\ "Vasile Alecsandri" University of Bacau, \\ timiras.laura@ub.ro
}

\begin{abstract}
The ERASMUS programme was evaluated from a lot of point of views. Depending on the interest of the evaluation, studies were conducted to uncover information related to subjects like: the scope of the programme, the type of participants in the programme, the factors motivating the students to be mobile, the cost and funding of student mobility, the study conditions during the study period, the recognition of achievements during the study period abroad on return, the socio-cultural effect of the mobility (like becoming more "European"), the personal development effects etc. Based on the results of a direct research take on the students of the Faculty of Economic Sciences of the "Vasile Alecsandri" University of Bacău, the paper presents a series of results with reference to: the knowledge held by the students with reference to the Erasmus + program, how they he perceives it, the reasons underlying the intention to benefit from the program, as well as those underlying the lack of interest in it. The research carried out was performed on a sample of 116 students from bachelor's degree studies - years II and III of studies selected according to non-probability criteria, so that the obtained results exclusively reveal their point of view.
\end{abstract}

\section{Keywords}

Erasmus+ programme; motivations; knowledge; interest

\section{JEL Classification}

M31

\section{Introduction}

ERASMUS is the European Union programme destinated for education and training and one of the best-known EU-level among higher education students. It was established in 1987 and it has a great impact on the possibility to study for more than 2 million people. The programme is named after Erasmus of Rotterdam (1465-1536), an important philosopher, theologian and humanist. The acronym ERASMUS comes from the syntagma EuRopean Community Action Scheme for the Mobility of University Students.

The birth of Erasmus programme was complicated, even if today it has a lot of supporters in all EU countries. Prior to the beginning of the programme, the European Commission had been supporting pilot student exchanges for six years before ERASMUS came into being. It proposed the original ERASMUS Programme in early 1986, but the reaction from EU Member States varied: those with substantial exchange programmes of their own rejected the programme while the remaining countries were generally in favour of it. Because of the budgetary aspects of the programme, in 1987 Erasmus was on the verge of being withdraw from the Commission actions, but after a 
compromise between Member States, the programme was adopted. In its first year of official functioning, 3244 students from 11 countries have been its beneficiaries.

After its foundation, programme suffered some transformations, being part or combing other similar programmes. In this direction, the ERASMUS Programme, together with several other education and training programmes, was incorporated into the Socrates Programme which was established in 1995. Socrates was replaced with the Socrates II Programme in January 2000. That, in turn, was replaced by the Lifelong Learning Programme (2007-2013) from 2007.

Erasmus + or Erasmus Plus is the new programme that combines all current EU programmes for education, training, youth and sport, which was launched in January 2014. Currently, the programme has a budget of EUR 14.7 billion, with the objective to give 4 million Europeans the opportunity to study, train and gain experience abroad. The Erasmus + programme, which will run until 2020, brings together seven previous programmes and it is set to provide opportunities for various categories of people and organizations. These seven programmes are:

- $\quad$ Lifelong learning programme

- Youth in Action Programme

- The Erasmus Mundus programme

- Tempus

- Alpha

- $\quad$ Edulink

- Cooperation programmes with the industrialized countries in the field of higher education

The scope of Erasmus + programme is to contribute to meeting the objectives of the Europe 2020 strategy for growth, jobs, equity and social inclusion, as well as the ET2020 strategic framework for education and training.

According to Commission, the programme aims to promote the sustainable development of partners in the field of higher education and to contribute to the achievement of the objectives of the EU youth strategy. It addresses the following topics:

- $\quad$ Reducing unemployment, especially among young people;

- Promoting adult education, especially in the area of new skills and the skills required on the labour market;

- $\quad$ Encourage the participation of young people in the European democratic life;

- Supporting innovation, cooperation and reform;

- $\quad$ Reducing the rate of early school leaving;

- $\quad$ Promoting cooperation and mobility with EU partner countries.

Since 1997, the Romanian institutions of higher education have started to be part of cooperation within Erasmus programme. Until 2016, more than 75,000 students from higher education, 62,000 young people in youth exchanges, including the European Voluntary Service, 20,000 young people in initial vocational training and over 30,000 teachers, auxiliary teachers, trainers and youth workers have benefited from the European Union programmes (Ghitulescu, 2017).

\section{Studies about Erasmus programme}

The ERASMUS programme was evaluated from a lot of point of views. Depending on the interest of the evaluation, studies were conducted to uncover information related to subjects like: the scope of the programme, the type of participants in the programme, the factors motivating the students to be mobile, the cost and funding of student mobility, the study conditions during the study period, the recognition of achievements 
during the study period abroad on return, the socio-cultural effect of the mobility (like becoming more "European"), the personal development effects etc.

From the point of view of categories of students who participate in the Erasmus programme, as study by Krzaklewska \& Krupnick, completed in 2007, identified two such categories:

- $\quad$ career oriented students - they most often come from disadvantaged groups they are students with family incomes low, generally girls, coming from the South, Center and Eastern Europe, they are older and their motivation is related to enrichment of academic knowledge, improvement the prospects for the future job etc.

- b. experience-oriented students - they are generally men, Erasmus students, from Western and Northern Europe countries, younger, and the reasons cited are related of the need to have new experiences, to learn something about different cultures, meeting new people, being independent, living in a foreign country .

Along with these categories of Erasmus students, the same authors, Krzaklewska \& Krupnik, introduce some of the main motives which sit at the base of the mobility. Table 1 shows the categories and the main motivations for mobility.

Table 1. Career-oriented and experience-oriented students and their motivations

\begin{tabular}{|c|c|c|}
\hline & Career - oriented & Experience - oriented \\
\hline $\begin{array}{l}\text { Reasons for going } \\
\text { abroad indicated as } \\
\text { important in survey }\end{array}$ & $\begin{array}{l}\text { - To improve academic } \\
\text { knowledge } \\
\text { To enhance future } \\
\text { employment } \\
\text { prospects } \\
\text { To practice foreign } \\
\text { language }\end{array}$ & $\begin{array}{ll}\text { - } & \text { To have new } \\
\text { - } & \text { To learn about } \\
& \text { different cultures } \\
\text { - } & \text { To have fun } \\
\text { - } & \text { To meet new people } \\
\text { - } & \text { To be independent } \\
\text { - } & \text { To live in a foreign } \\
& \text { country }\end{array}$ \\
\hline $\begin{array}{l}\text { Student groups who } \\
\text { were more likely to } \\
\text { belong to specific } \\
\text { category }\end{array}$ & $\begin{array}{ll}\text { - } & \text { Non Erasmus } \\
\text { exchange students } \\
\text { Females with lower } \\
\text { family income } \\
\text { coming from South } \\
\text { (e.g. Spain) Central } \\
\text { and East European } \\
\text { Countries (e.g. } \\
\text { Poland) } \\
\text { Older } \\
\end{array}$ & $\begin{array}{l}\text { - } \\
\text { Erasmus students } \\
\text { familes with higher } \\
\text { famcome } \\
\text { coming from West } \\
\text { and North European } \\
\text { countries } \\
\text { Younger }\end{array}$ \\
\hline Quote & $\begin{array}{l}\text { With my Erasmus Program I } \\
\text { had the opportunity to start an } \\
\text { international work career } \\
\text { (Bruno Fernandes) }\end{array}$ & $\begin{array}{l}\text { I always wanted to smell } \\
\text { freedom and independence } \\
\text { (Katerina Markova) }\end{array}$ \\
\hline
\end{tabular}

Source: Krzaklewska, Ewa; Krupnik, Seweryn (2008), “The Role of the Erasmus Programme in Enhancing Intercultural Dialogue. Presentation of the Results from the Erasmus Student Network Survey 2007".

Proceedings of the 4th International Barcelona Conference on Higher Education, Vol. 6. Higher education for intercultural dialogue and multiculturalism. Barcelona: GUNI. Available at http://www.guni-rmies.net.

In another study regarding the motivations of Erasmus student, one of the mentioned authors distinguishes four areas of motivation, which included 11 categories (Krzaklewska, 2008): 
1. Academic (improving academic knowledge, studying in a different educational system, hoping that it will be useful for future employment/work);

2. $\quad$ Linguistic (practicing a foreign language);

3. Cultural (learning about different cultures, living in a foreign country);

4. Personal (having new experiences, having fun, meeting new people, being independent, developing as a person)

Other studies use push-pull framework of student mobility in studying the motivations. Push factors are elements that operate in the home country of the student whereby they stimulate the individual to study abroad; pull factors are elements of a host country that attract a student to study abroad. A combination of push and pull factors determines a student's decision to study abroad then his/her destination choice (Lesjak et al, 2015). Gonzalez et al, 2011 find out that European student mobility is as a dual phenomenon: " On the one hand, student mobility is influenced by economic variables, such as the price level of host countries or the geographical distance as a proxy for transport costs, and, ... on the other hand, the observed tendency to choose countries whose climate is warm, above other considerations, brings into discussion the notion of student mobility as a leisure activity, as if European students collectively were trying to enjoy from the lifelong unique experience of living abroad".

Other studies regarding Erasmus mobility concentrated on the effect of the mobility on the beneficiaries. Again, the effects can be put in different categories (Dolga et al, 2015):

effects on the professional and scientific development of exchange students (acquisition of scientific knowledge and skills, acquisition of professional knowledge and skills, acquisition of foreign language knowledge and skills, identification of academic / scientific and professional opportunities);

- $\quad$ effects on certain aspects of the students' personality (development of relational skills, personal system of values, self-confidence, the feeling of independence, the feeling of belonging to a group or a community, attitude towards work and study, attitude towards the chosen profession, attitude towards family);

- $\quad$ effects on certain aspects related to the social life and the interpersonal relations of exchange students (interpersonal relations with foreigners, relations with locals - Romanians, interpersonal relations with family members and close friends);

- $\quad$ effects on other aspects of the students' life (eating habits, spare time habits, future career plans, future plan regarding family life

effects on level of agreement between the Erasmus programme and the needs of students and of the university

More pragmatic studies focused on the relation between the mobility and transition to employment and early career. Teichler and Janson (2007), after participating in the study The Professional Value of ERASMUS Mobility. Final Report. Presented to the European Commission - DG Education and Culture (Bracht et al, 2006) conclude in 2007 that "ERASMUS students view the study period abroad as leading to international mobility, international competences, and visibly international work tasks while hardly promising career enhancement as compared to formerly nonmobile students".

An interesting subject of study, in the context of Erasmus programme, was the existence and the formation of "European identity". Mitchell studied, in 2012, Erasmus programme in terms of civic experiences. Her study identified and widely validated three assumptions: (a) Erasmus students engage insignificant contact with other Europeans and (b) they become more interested in Europe and other Europeans and (c) self-identify as European. 
Oborune (2013) study, based on Van Mol (2009) work came to the conclusion that "ERASMUS programme influences students European identity, but on the other hand, students who take part differ from non-mobile students - have more multicultural background, stronger national and European identity. The programme is a catalyst rather than promoter ...".

This complex reality of Erasmus programme needs additional work, and in this direction our paper focuses on identifying and validating motivations and factors associated with Erasmus+ experience, from the point of view of the students of a Romanian university.

\section{Research methodology}

The research was carried out among the students from the bachelor's studies with frequency - years II and III, of the Faculty of Economic Sciences of the "Vasile Alecsandri" University of Bacău. The sample surveyed was 116 students, representing about $48 \%$ of the total. The sampling method used was an improbable one - all students attending the didactic activities were included in the sample in the first week of March 2019 as long as they wished to participate in the study; which is why the research was exploratory, the results representing only the point of view of the investigated students. Despite their unrepresentative character, the results provide us with useful information, which are indicative in nature, on the investigated issue and can also be the basis for the formulation of hypotheses for extensive research, representative for the entire community of students as potential beneficiaries of the Erasmus + program.

\section{Research results}

Regarding the degree of knowledge of the Erasmus + programme by the investigated students, $100 \%$ stated that they had heard about it, but the opportunities offered are known to a small extent by those to whom they are addressed.

Most of the students know that through the Erasmus + programme they can study abroad (over 79\% have information about it) and, much less, they know that they can benefit from internships, vocational training, etc. abroad - about $40 \%$. However, the other opportunities offered by the Erasmus + programme are little known. Thus, over $60 \%$ of students have not heard that within the Erasmus + programme can benefit from the Erasmus Mundus joint master's program (EMJMD) or Erasmus + loans for the masters and over $50 \%$ of them have not heard that the programme offers financial support for individuals with special needs. Also, for the most part, those who have heard about the opportunities mentioned above (the Erasmus Mundus joint master's program, Erasmus + loans for the masters, financial support for people with special needs) offered by the Erasmus + programme, are not aware of extensive information.

This low level of knowledge can only be partially attributed to the absence of students from Erasmus + presentations that are regularly held in the institution, in the context where, according to the data in the table below, there are no major differences between the declared level of knowledge of those who they participated, respectively of those who did not participate in such presentations. The biggest differences from this point of view are recorded in terms of the possibility to benefit from internships, vocational training abroad etc.: $50 \%$ of students who participated in Erasmus + presentations and only $28.5 \%$ of those who did not attend presentations have information about this opportunity.

The differences in the level of knowledge of the different opportunities between those who participated and those who did not participate in presentations, appreciated by us as small, prove the existence of factors that affect the efficiency of the communication process, factors that can be held by students as well, in their quality of receivers (such 
as inattention generated by total lack of interest / existence of other priorities, forgetfulness, etc.) but also by those who organize such presentations, in their capacity as broadcasters (such as unattractive presentations, the use of a specialized language not adapted to the audience, etc.). Also, it should be kept in mind that information about the Erasmus+ programme is also transmitted by other means - advertising materials, web pages, etc., showing a low degree of knowledge of the benefits of the program, attesting to a lack of efficiency of the entire communication process, as we have stated previously, the cases can be kept both by the transmitter and / or the receiver of the information.

Considering that the low level of knowledge refers strictly to the 116 students investigated, it is necessary to verify this phenomenon at the level of numerous students, through representative research. If it is proven that the low level of knowledge of the program characterizes the entire student community, identifying the factors that affect the efficiency of the communication request is a priority in order to take measures to improve it and, implicitly, to increase the student's interest in the Erasmus+ programme.

Table 2. The structure of the students investigated according to the degree of knowledge of the different opportunities offered by the Erasmus+ programme, by total and by categories depending on whether they participated in Erasmus + presentations

\begin{tabular}{|c|c|c|c|c|c|c|}
\hline \multicolumn{7}{|c|}{ - $\%$ in total category - } \\
\hline No. & Opportunity & 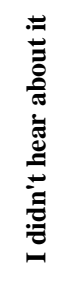 & 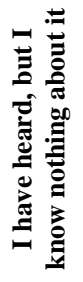 & 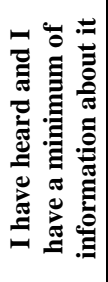 & 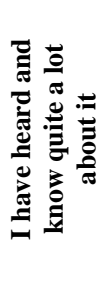 & Total \\
\hline \multicolumn{7}{|c|}{ Total investigated students } \\
\hline 1 & Studies abroad & 1.7 & 19.0 & 62.1 & 17.2 & 100.0 \\
\hline 2 & $\begin{array}{l}\text { Internships (practice, vocational training, } \\
\text { etc.) }\end{array}$ & 22.4 & 37.9 & 29.3 & 10.3 & 100.0 \\
\hline 3 & $\begin{array}{l}\text { Erasmus Mundus Joint Master Program } \\
\text { (EMJMD) }\end{array}$ & 63.8 & 22.4 & 8.6 & 5.2 & 100.0 \\
\hline 4 & Erasmus + loans for masters & 60.3 & 31.0 & 6.9 & 1.7 & 100.0 \\
\hline 5 & $\begin{array}{l}\text { Financial support for people with special } \\
\text { needs }\end{array}$ & 53.4 & 32.8 & 10.3 & 3.4 & 100.0 \\
\hline \multicolumn{7}{|c|}{ Students who participated in Erasmus + presentations } \\
\hline 1 & Studies abroad & 3.3 & 16.7 & 60.0 & 20.0 & 100.0 \\
\hline 2 & $\begin{array}{l}\text { Internships (practice, vocational training, } \\
\text { etc.) }\end{array}$ & 13.3 & 36.7 & 36.7 & 13.3 & 100.0 \\
\hline 3 & $\begin{array}{l}\text { Erasmus Mundus Joint Master Program } \\
\text { (EMJMD) }\end{array}$ & 50.0 & 30.0 & 13.3 & 6.7 & 100.0 \\
\hline 4 & Erasmus + loans for masters & 46.7 & 40.0 & 10.0 & 3.3 & 100.0 \\
\hline 5 & $\begin{array}{l}\text { Financial support for people with special } \\
\text { needs }\end{array}$ & 50.0 & 30.0 & 16.7 & 3.3 & 100.0 \\
\hline \multicolumn{7}{|c|}{ Students who do not participated in Erasmus + presentations } \\
\hline 1 & Studies abroad & 0.0 & 21.4 & 64.3 & 14.3 & 100.0 \\
\hline 2 & $\begin{array}{l}\text { Internships (practice, vocational training, } \\
\text { etc.) }\end{array}$ & 32.1 & 39.3 & 21.4 & 7.1 & 100.0 \\
\hline 3 & $\begin{array}{l}\text { Erasmus Mundus Joint Master Program } \\
\text { (EMJMD) }\end{array}$ & 78.6 & 14.3 & 3.6 & 3.6 & 100.0 \\
\hline 4 & Erasmus + loans for masters & 75.0 & 21.4 & 3.6 & 0.0 & 100.0 \\
\hline 5 & $\begin{array}{l}\text { Financial support for people with special } \\
\text { needs }\end{array}$ & 57.1 & 35.7 & 3.6 & 3.6 & 100.0 \\
\hline
\end{tabular}


The students' perception of the Erasmus+ programme was evaluated by means of statements, indicating to what extent the respective statement describes the evaluated program. Thus, according to the results presented in table 3 , as well as those of figure 1 , for the investigated students, the Erasmus+ programme is primarily a means of visiting other countries / places (the corresponding statement recorded the highest average score), but also: a means of knowing new cultures / customs, a means of practicing and improvement of English language proficiency, a starting point for those who wish to continue their studies abroad, a means of knowing education systems in other countries, a starting point for those who want to find a job / to establish abroad, a means of personal development, a means of connecting friends / socializing and, finally, a means of improving professional perspectives.

Table 3 The structure of the students interviewed according to the extent to which they consider that different statements describe the Erasmus + program, evaluated on a scale from 1-Not at all, to 5 - To a great extent

\begin{tabular}{|c|l|c|c|c|c|c|c|c|}
\hline No. & \multicolumn{1}{|c|}{ Statement } \\
\hline 1 & $\begin{array}{l}\text { N } \\
\text { about education systems } \\
\text { in other countries }\end{array}$ & 0.0 & 1.7 & 13.8 & 27.6 & 56.9 & 0.0 & 100.0 \\
\hline 2 & $\begin{array}{l}\text { It is a means of improving } \\
\text { professional prospects } \\
\text { (CV improvement } \\
\text { employment advantage) }\end{array}$ & 0.0 & 5.2 & 19.0 & 31.0 & 44.8 & 0.0 & 100.0 \\
\hline 3 & $\begin{array}{l}\text { It is a means of practicing } \\
\text { and improving English } \\
\text { language proficiency }\end{array}$ & 0.0 & 3.4 & 10.3 & 25.9 & 58.6 & 1.7 & 100.0 \\
\hline 4 & $\begin{array}{l}\text { It is a means of personal } \\
\text { development (increasing } \\
\text { confidence in one's own } \\
\text { strengths, ability to adapt } \\
\text { to new situations) }\end{array}$ & 0.0 & 3.4 & 12.1 & 37.9 & 46.6 & 0.0 & 100.0 \\
\hline 5 & $\begin{array}{l}\text { It is a means of learning } \\
\text { about new cultures / } \\
\text { customs }\end{array}$ & 0.0 & 1.7 & 8.6 & 27.6 & 62.1 & 0.0 & 100.0 \\
\hline 6 & $\begin{array}{l}\text { It is a means of } \\
\text { connecting friends / } \\
\text { socializing }\end{array}$ & 0.0 & 3.4 & 15.5 & 39.7 & 41.4 & 0.0 & 100.0 \\
\hline 7 & $\begin{array}{l}\text { It is a means of visiting } \\
\text { other countries / places }\end{array}$ & 0.0 & 0.0 & 6.9 & 27.6 & 62.1 & 3.4 & 100.0 \\
\hline $\begin{array}{l}\text { It is a starting point for } \\
\text { those who want to } \\
\text { continue their studies } \\
\text { abroad }\end{array}$ & $\begin{array}{l}\text { It is a starting point for } \\
\text { those who want to find a } \\
\text { job / settle abroad }\end{array}$ & 0.0 & 0.0 & 22.4 & 24.1 & 50.0 & 3.4 & 100.0 \\
\hline
\end{tabular}




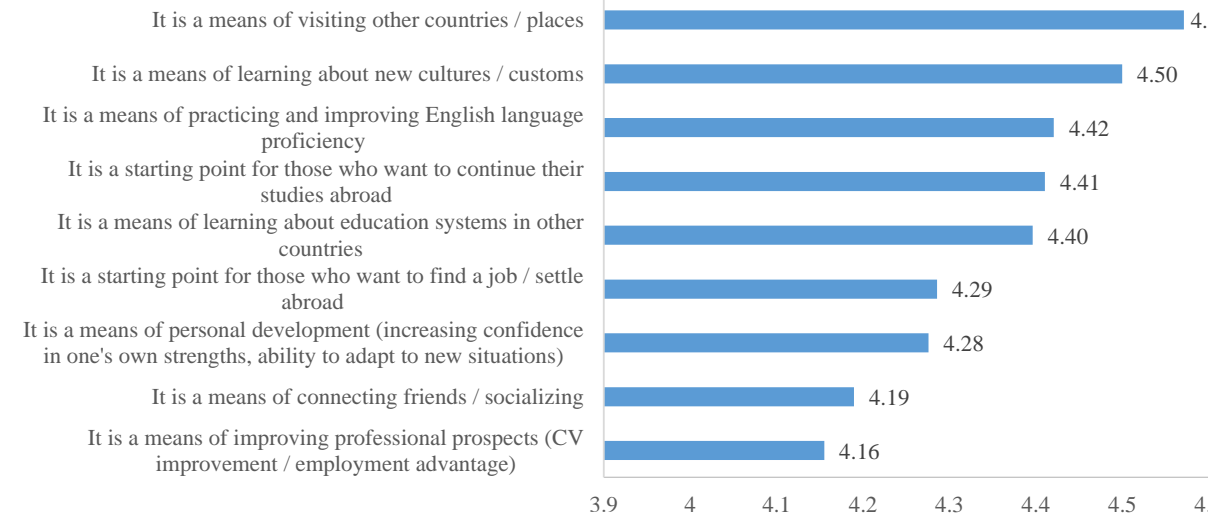

Figure 1. The average scores attesting the extent to which the interviewed students consider that different statements describe the Erasmus+ programme, evaluated on a scale from 1-Not at all, to 5 - To a great extent

Referring to the experience and / or the intention to benefit from the Erasmus+ programme, out of the total of the investigated students only $3.4 \%$ had an Erasmus+ experience and all want to relive it. $22.4 \%$ of the students, not having an Erasmus+ experience, indicated their intention to access the program, but most - over $74 \%$, are not interested in the program (they did not benefit and do not wish to benefit from it). (Figure 2)

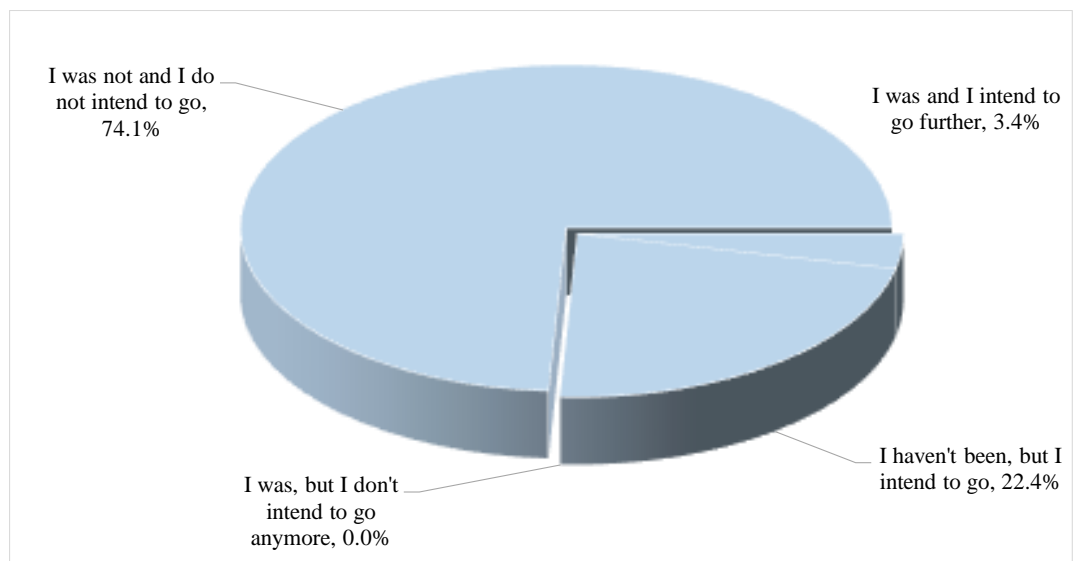

Figure 2. The structure of the students investigated according to the experience and / or the intention to benefit from the Erasmus+ programme (\% in total students)

Referring to the students who benefited from the Erasmus+ programme (through mobility of studies and internships), the main reasons underlying the decision to leave in such mobility were: the desire for personal development, bonding with friends / socializing and visiting other countries. All the beneficiary students declared themselves satisfied with the experience, confirmed by the intention to leave again in such mobility.

Regarding students who have not benefited but intend to benefit from the Erasmus+ programme, the main reasons stated as underlying this intention are: improving professional prospects (approximately $70 \%$ of those who did not benefit but wish to benefit from the Erasmus+ programme indicated this reason among the first 3 most 
important), the practice and improvement of the linguistic knowledge of English and personal development (both indicated by about $54 \%$ of the students) (Figure 3 ).

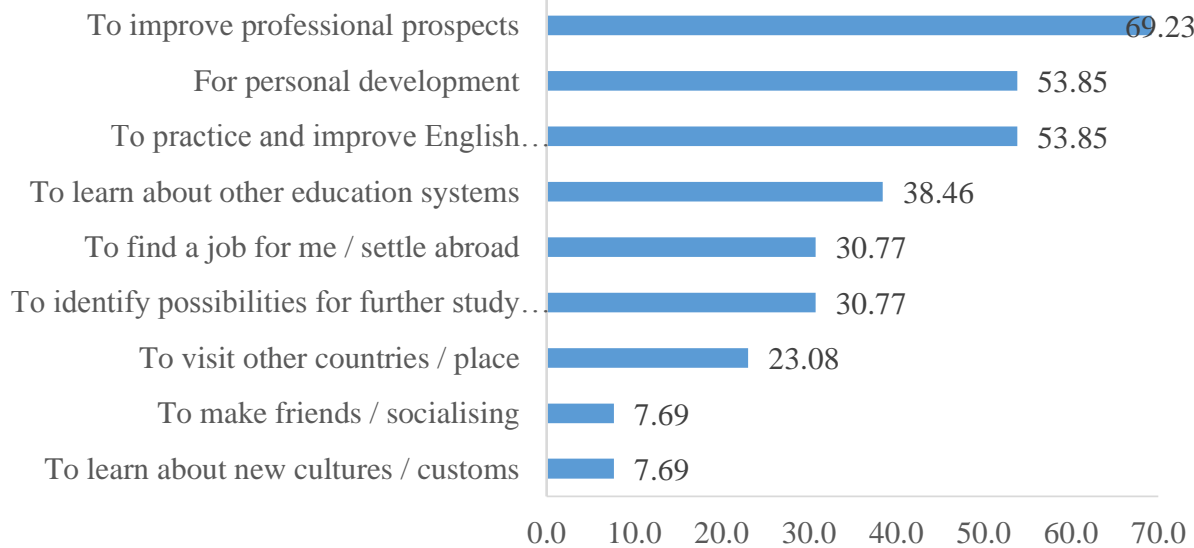

Figure 3. The share of students who have indicated a certain reason as being the basis of the intention to go into Erasmus+ mobility, in total students who have declared that they have not been, but intend to go in mobility (\% in total students)

Note: each student has indicated maximum 3 reasons, the most important ones

Being overwhelming (about 3 quarters of the total students interviewed), the students who neither benefited nor intend to benefit from the Erasmus+ programme indicated, in particular, the main reasons for the lack of this intention: the linguistic difficulties generated by lack of knowledge / insufficient knowledge of the language of the host country (approximately 53\% of those who did not benefit and do not wish to benefit from the Erasmus + programme indicated this reason among the first 3 most important ones), fearing the academic demands of the host university (approximately 49\%), linguistic difficulties arising from insufficient knowledge of English and the existence of other priorities (approximately 40\% each) (Figure 4).

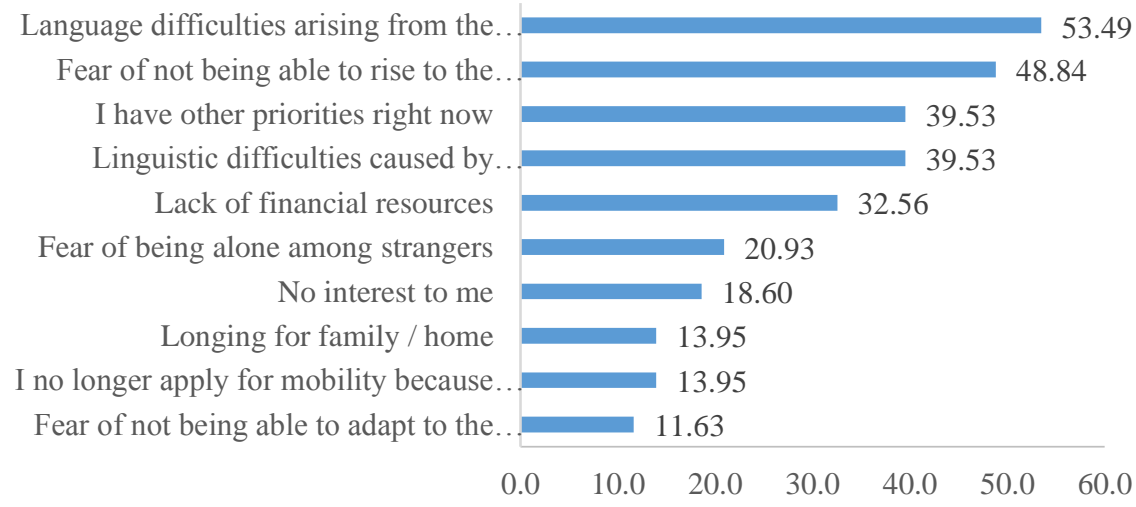

Figure 4. The share of students who have indicated a reason as being based on the lack of intention to go into an Erasmus + mobility, in total students who stated that they were not and do not intend to go on a mobility (\% in total students)

Note: each student has indicated maximum 3 reasons, the most important ones

\section{Conclusions}

The main results of the research, representing exclusively the point of view of the 116 students from the bachelor's degree studies - years II and III, of the Faculty of Economic 
Sciences of the "Vasile Alecsandri" University of Bacău, who were investigated, with reference to the information held and the way they perceive the Erasmus+ programme, the reasons for the manifestation and the lack of intention to benefit from it are presented as follows:

- there is a relatively low level of knowledge of the opportunities offered by the Erasmus+ programme by the investigated students. In general, it is known that through the Erasmus+ programme you can benefit from studies abroad (over $79 \%$ of the respondents said they have information about it) and, to a lesser extent, the program offers the opportunity to go to internships, vocational training, abroad etc. (approximately 40\%). Other opportunities offered by the program: the Erasmus Mundus joint master's program (EMJMD), Erasmus + loans for the masters and financial support for people with special needs, however, record a very low level of knowledge, most of the respondents declaring that they have not heard of them;

- referring to how the Erasmus+ programme is perceived, for the investigated students this is especially a means of knowing new cultures / habits, a means of practicing and improving the English language skills, a starting point for those who want to learn, a way to continue studies abroad, as well as a means to learn about education systems in other countries;

- of the total investigated students, a low weight - $3.4 \%$ benefited from the Erasmus+ programme, the satisfaction gained as a result of this experience being confirmed by the unanimous intention to benefit from the program again;

- $\quad 22.4 \%$ of the students did not benefit, but wish to benefit from the Erasmus+ programme, the main reasons indicated by them as being the basis of this intention being: improving professional perspectives, practicing and improving English language skills, personal development;

- $\quad$ about 3 quarters of the total students interviewed have not benefited and do not wish to benefit from the Erasmus+ programme, the linguistic difficulties generated by the ignorance / insufficient knowledge of the language of the host country, the fear of the academic demands of the host university, the linguistic difficulties generated of the insufficient knowledge of the English language and the existence of other priorities, being the main reasons indicated to a greater extent by them as being the basis of the lack of interest.

\section{References}

Bracht Oliver, Engel Constanze, Janson Kerstin, Over Albert, Schomburg Harald, Teichler Ulrich (2006), The Professional Value of ERASMUS Mobility. Final Report. Presented to the European Commission - DG Education and Culture.

Dolga L., Filipescu H., Popescu-Mitroia M.M., Mazilescu C.A. (2015), Erasmus Mobility Impact On Professional Training And Personal Development Of Students Beneficiaries, Procedia - Social and Behavioral Sciences 191, 1006 1013.

Ghitulescu Radu (2017), De 20 de ani în România, Programul Erasmus schimbă vieţi, deschide minţi, Market Watch, no. 195, available at http://www.marketwatch.ro/articol/15655/De_20_de_ani_in_Romania_Progra mul_Erasmus_schimba_vieti_deschide_minti/

Krzaklewska, Ewa (2008), Students, Staff and Academic Mobility in Higher Education, Michael Byram \& Fred Dervin (eds.), Cambridge Scholars Press.

Krzaklewska, Ewa; Krupnik, Seweryn (2008), "The Role of the Erasmus Programme in Enhancing Intercultural Dialogue. Presentation of the Results from the Erasmus Student Network Survey 2007'. Proceedings of the 4th International Barcelona Conference on Higher Education, Vol. 6. Higher education for 
intercultural dialogue and multiculturalism. Barcelona: GUNI. Available at http://www.guni-rmies.net.

Kumar V., Aaker, D.A., Day G.S. (1999), Essentials of Marketing research, John Wiley \& Sons, Inc., New York Chichester Weinheim Brisbane Singapore Toronto.

Lesjak Miha, Juvan Emil, Ineson Elizabeth M., Yap Matthew H. T., Podovsovnik Axelsson Eva (2015), Erasmus student motivation: Why and where to go?, Higher Education, 70:845-865, Springer.

Mazilescu Crisanta-Alina, Dolga Lia, Filipescu Hannelore Elfride, Popescu-Mitroi Maria Monica (2019), Erasmus +, o punte de legătură între universități și organizații, Eurostampa, Timisoara.

Mitchell Kristine (2012) Student mobility and European identity: Erasmus study as a civic experience?, Journal of Contemporary European Research, Vol. 8 Issue 4.

Oborune Karina (2013), Becoming more European after ERASMUS? The Impact of the ERASMUS Programme on Political and Cultural Identity, Epiphany: Vol. 6, No. 1.

Rodriguez Gonzalez Carlos, Mesanza Ricardo Bustillo, Mariel Petr (2011), The determinants of international student mobility flows: an empirical study on the Erasmus programme, Higher Education, 62:413-430, Springer.

Teichler Ulrich, Janson Kerstin (2007), The Professional Value of Temporary Study in Another European Country: Employment and Work of Former ERASMUS Students, Journal of Studies in International Education, 11: 486.

Van Mol, C. 2009. "The Influence of European Student Mobility on European Identity and subsequent migration aspirations. A Theoretical Framework on European Student Mobility" Working paper No. 1 Universiteit Antwerpen. 